$\begin{array}{rr}\text { FIT(1)PATOLOGI } & \text { Volume } 13, \text { Nomor 3, Mei } 2017 \\ \text { IN DONESIA } & \text { Halaman 105-111 } \\ \text { ISSN: } 0215-7950 & \text { DOI: } 10.14692 / \text { jif. } 13.3 .105\end{array}$

KOMUNIKASI SINGKAT

\title{
Penapisan dan Identifikasi Bakteri Kitinolitik Penghambat Pertumbuhan Ganoderma boninense in Vitro
}

\author{
Screening and Identification of Chitinolitic Bacteria Inhibiting \\ Ganoderma boninense in Vitro
}

\author{
Risky Hadi Wibowo, Nisa Rachmania Mubarik*, Iman Rusmana, Maggy Thenawidjaya \\ Institut Pertanian Bogor, Bogor 16680
}

\begin{abstract}
ABSTRAK
Bakteri kitinolitik memiliki kemampuan menghasilkan enzim kitinase dan banyak dilaporkan sebagai agens biokontrol. Penelitian ini bertujuan memperoleh bakteri kitinolitik yang bersifat antagonis terhadap pertumbuhan Ganoderma boninense penyebab busuk pangkal batang pada kelapa sawit. Sebanyak 63 galur bakteri penghasil enzim kitinase berhasil diisolasi dari tanah di Taman Nasional Bukit Dua Belas dan dari perkebunan kelapa sawit di Provinsi Jambi. Seluruh galur diseleksi untuk melihat potensinya menghambat pertumbuhan $G$. boninense secara in vitro. Tiga galur TB04-05, SW0111, dan SW02-08 paling potensial menekan dan menghambat pertumbuhan miselium $G$. boninense secara in vitro. Berdasarkan uji aktivitas spesifik, ketiganya memiliki aktivitas masing-masing sebesar $6.3072 \mathrm{U} \mathrm{mg}^{-1}$ protein, $6.0385 \mathrm{U} \mathrm{mg}^{-1}$ protein, dan $6.1279 \mathrm{U} \mathrm{mg}^{-1}$ protein setelah diinkubasi 24 jam. Identifikasi 16S RNA menunjukkan galur TB04-05 berkerabat dekat dengan Bacillus cereus, sedangkan SW01-11 dan SW02-08 berkerabat dekat dengan Bacillus thuringiensis.
\end{abstract}

Kata kunci: busuk pangkal batang, Elaeis guineensis, kelapa sawit, kitinase, 16S RNA

\begin{abstract}
Chitinolytic bacteria have been reported as biocontrol agents and have the ability to produce chitinase enzymes. The objective of the research was to obtain chitinase producing bacteria that had antagonistic activity to Ganoderma boninense, a causal agent of basal stem rot on oil palm. A total of 63 isolates of chitinase producing bacteria were isolated from soil of Bukit Dua Belas National Park and oil palm plantation in Jambi Province; all was screened for their potency in inhibiting G. boninense in vitro. Three isolates designated TB04-05, SW01-11, and SW02-08 were potentially suppressed and inhibited the mycelium growth of $G$. boninense in vitro. Based on their specific chitinase activity, these three isolates produced the highest level of chitinase enzyme of $6.3072 \mathrm{U} \mathrm{mg}^{-1}$ protein, $6.0385 \mathrm{U} \mathrm{mg}^{-1}$ protein and $6.1279 \mathrm{U} \mathrm{mg}^{-1}$ protein, respectively after $24 \mathrm{hr}$ incubation. Based on 16S RNA identification, strain TB04-05 had similarity with Bacillus cereus, whereas strains SW01 and SW02-08 had similarity with Bacillus thuringiensis.
\end{abstract}

Key words: basal stem rot, chitinase, Elaeis guineensis, oil palm, 16S RNA

*Alamat penulis korespondensi: Departemen Biologi, Fakultas Matematika dan Ilmu Pengetahuan Alam, Institut Pertanian Bogor, Kampus IPB Dramaga, Bogor 16680, Indonesia.

Tel: +62251-8622833, Faks: +62251-8622833, Surel: nrachmania@ipb.ac.id 
Kelapa sawit (Elaeis guineensis) adalah tanaman andalan Indonesia penghasil devisa nonmigas. Salah satu kendala dalam budi daya kelapa sawit ialah penyakit busuk pangkal batang (BPB) yang disebabkan oleh Ganoderma boninense, terutama pada perkebunan yang sudah tua. Penyakit ini dilaporkan menyebabkan kerugian sekitar 50-80\% per ha (Cooper et al. 2011). Banyak upaya untuk pengendalian penyakit BPB dengan fungisida kimia, tetapi keamanan lingkungan menjadi pertimbangan yang harus diperhatikan. Alternatif yang dapat dilakukan ialah menggunakan agens pengendali hayati. Beberapa mikrob mampu menekan pertumbuhan $G$. boninense dan cendawan patogen lainnya. Bacillus cepacia, Enterobacter spp., dan Pseudomonas aeruginosa mampu menghambat pertumbuhan $G$. boninense (Bivi et al. 2010; Suryanto et al. 2012).

Pengendalian hayati menggunakan berbagai mikroorganisme seperti bakteri kitinolitik sudah banyak digunakan (Duffy 1995). Bakteri kitinolitik mampu menghasilkan enzim kitinase dan banyak dilaporkan sebagai agens biokontrol. Kitinase merupakan enzim ekstraseluler yang berperan penting dalam menghidrolisis kitin. Kitinase diproduksi secara alami pada berbagai organisme seperti bakteri, artopoda, vertebrata, dan tanaman. Fungsi fisiologis dari kitinase bergantung pada sumbernya. Pada tanaman, umumnya kitinase diinduksi oleh adanya faktor cekaman seperti infeksi patogen yang mengandung kitin. Pada organisme yang mengandung kitin pada dinding selnya atau struktur yang lainnya seperti fungi, kitinase diketahui berperan dalam germinasi spora, pertumbuhan hifa dan percabangannya serta perkembangan miselium (Lopes et al. 2008). Substrat utama dari kitinase ialah kitin yang merupakan senyawa biopolimer berantai panjang dan tidak bercabang (Sanjaya dan Yuanita 2007). Tiap rantai polimer umumnya terdiri atas 2000 5000 unit monomer N-asetil-D-glukosamin yang terpaut melalui ikatan $\beta$ (1-4) glukosa, yang merupakan polimer kedua melimpah di alam setelah selulosa (Patil et al. 2000).

Penelitian sebelumnya telah melaporkan penapisan bakteri kitinolitik dari tanah perakaran kelapa sawit di Taman Nasional Bukit Dua Belas (TNBD), Jambi mampu menghambat pertumbuhan cendawan patogen penyebab hawar kelapa sawit, baik menggunakan sel, enzim kasar dan kitinase hasil pengendapan (Haryanto 2013; Asril et al. 2014). Namun demikian masih belum banyak laporan penghambatan kitinase terhadap $G$. boninense. Tujuan penelitian ini untuk menapis dan mengidentifikasi bakteri penghasil kitinase asal tanah TNBD dan perkebunan kelapa sawit dalam menghambat pertumbuhan $G$. boninense secara in vitro.

Pengambilan sampel tanah dilakukan di tanah sekitar TNBD dan perkebunan sawit PT Humusindo Tbk, Kabupaten Sarolangun, Provinsi Jambi. Sebanyak $250 \mathrm{~g}$ tanah diambil pada masing-masing plot area dengan memakai paralon pada kedalaman $0-10 \mathrm{~cm}$.

Sebanyak 3 g tanah dari tiap lokasi dicampur di dalam $30 \mathrm{~mL}$ medium kitin cair $\left(0.3 \%\right.$ koloidal kitin, $0.1 \% \quad \mathrm{MgSO}_{4} \cdot 7 \mathrm{H}_{2} \mathrm{O}$, $0.02 \% \mathrm{~K}_{2} \mathrm{HPO}_{4}, 0.1 \%$ ekstrak khamir) dan diinkubasi pada suhu $30{ }^{\circ} \mathrm{C}$ selama 24 jam. Semua suspensi diencerkan berseri dari 10 ${ }^{6}-10^{-8}$ di dalam $\mathrm{NaCl} 0.85 \%$. Suspensi disebar pada medium agar-agar kitin (komposisi sama dengan kitin cair ditambah 2\% agar-agar) dan diinkubasi pada suhu $37{ }^{\circ} \mathrm{C}$ selama 48 jam. Setiap koloni dari bakteri yang berbeda dimurnikan pada medium kitin sebagai biakan tunggal dan dipilih berdasarkan adanya zona bening di sekitar medium kitin. Zona bening terbentuk karena terjadinya pemutusan ikatan $\beta-1,4$ homopolimer $\mathrm{N}$-asetilglukosamin pada kitin oleh kitinase menjadi monomer $\mathrm{N}$-asetilglukosamin dan glukosa yang selanjutkan akan digunakan kembali oleh sel bakteri sebagai sumber karbon untuk pertumbuhannya (Thompson 2001).

Galur bakteri kemudian diinkubasi pada inkubator goyang pada suhu $37{ }^{\circ} \mathrm{C}$ dengan kecepatan 120 rpm selama 72 jam, disentrifugasi selama 20 menit dengan kecepatan $3400 \times$ g pada suhu $4{ }^{\circ} \mathrm{C}$ (Sentrifuge Hermle dengan rotor 220.97). Supernatan yang diperoleh merupakan enzim ekstrak kasar yang selanjutnya diukur aktivitas kitinase dan kadar proteinnya. Galur yang memiliki 
aktivitas spesifik kitinase terbaik ditetapkan sebagai galur terpilih.

Aktivitas antagonis terhadap $G$. boninense diuji menggunakan biakan sel 24 jam dan ekstrak kasar kitinase dari galur bakteri dengan metode agar well diffusion. Galur $G$. boninense yang diuji merupakan koleksi dari PT. Perkebunan Nusantara IV (Persero) Unit Usaha Marihat, Pematang Siantar. Sebanyak $100 \mu \mathrm{L}$ biakan sel atau ekstrak kasar kitinase dimasukkan ke dalam sumur yang dibuat $3 \mathrm{~cm}$ dari pinggir cawan petri dan $3 \mathrm{~cm}$ dari miselium $G$. boninense umur 3 hari pada medium agaragar dekstrosa kentang (ADK). Akuades steril digunakan sebagai kontrol. Hambatan pemanjangan miselium $G$. boninense yang mengarah ke cakram yang berisi biakan sel atau enzim dan akuades (kontrol) diamati secara visual setiap hari selama 7 hari pada suhu $25^{\circ} \mathrm{C}$. Persentase penghambatan G. boninense diukur dengan menggunakan persamaan:

$$
\% \text { Penghambatan }=\frac{r_{1}-r_{2}}{r_{1}} \times 100 \% \text {, dengan }
$$

$\mathrm{r}_{1}$, panjang pertumbuhan miselium ke arah tepi petri $(3 \mathrm{~cm}) ; \mathrm{r}_{2}$, panjang miselium ke arah sumur (Fokkema 1983).
DNA genom bakteri terpilih yang menghasilkan zona hambat paling besar terhadap $G$. boninense diekstraksi dengan menggunakan Presto ${ }^{\mathrm{TM}}$ Mini gDNA Bacteria Kit (Genaid). Amplifikasi gen dilakukan dengan PCR menggunakan primer spesifik 63F (5'-CAG GCC TAA CAC ATG CAA GTC-3') dan 1387r (5'-GGG CGG WGT GTA CAA GGC-3') (Marchesi et al. 1998). Produk PCR dimurnikan dan diurutkan DNAnya. Hasil pengurutan DNA dianalisis menggunakan program Bioedit kemudian disejajarkan dengan data base Gen 16S rRNA menggunakan program BLAST-N. Analisis filogenetika dilakukan menggunakan program MEGA 6.

Sebanyak 63 galur bakteri kitinolitik berhasil diisolasi (Tabel 1). Dari 63 galur kitinolitik hanya 10 galur yang berpotensi menghambat pertumbuhan hifa $G$. boninense setelah diuji antagonis (Tabel 2). Kitinase umumnya diproduksi oleh bakteri pada fase stasioner pada 24-72 jam inkubasi (Mubarik et al. 2010; Asril et al. 2014). Indeks zona bening yang dihasilkan dari 10 galur kitinolitik sekitar $0.2-4.0$ sedangkan

Tabel 1 Galur bakteri kitinolitik asal Taman Nasional Bukit Dua Belas dan perkebunan kelapa sawit di Provinsi Jambi

\begin{tabular}{lcccc}
\hline Lokasi sampel & $\begin{array}{c}\text { Jumlah titik/ } \\
\text { plot sampel }\end{array}$ & $\begin{array}{c}\text { Kode } \\
\text { sampel }\end{array}$ & $\begin{array}{c}\text { Total bakteri } \\
\left(\mathrm{cfu} \mathrm{g}^{-1}\right)\end{array}$ & $\begin{array}{c}\text { Total galur } \\
\text { bakteri kitinolitik }\end{array}$ \\
\hline Taman Nasional Bukit 12 & 3 & TB04 & $55 \times 10^{5}$ & 18 \\
Taman Nasional Bukit 12 & 3 & TB03 & $38 \times 10^{4}$ & 14 \\
Perkebunan sawit PT Humusindo & 3 & SW01 & $10 \times 10^{4}$ & 12 \\
Perkebunan sawit PT Humusindo & 3 & SW02 & $40 \times 10^{5}$ & 19 \\
\hline Total galur & & & 63 \\
\hline
\end{tabular}

Tabel 2 Hasil penapisan bakteri kitinolitik terhadap Ganoderma boninense

\begin{tabular}{lccc}
\hline $\begin{array}{l}\text { Bakteri } \\
\text { kitinolitik }\end{array}$ & Indeks kitinolitik & $\begin{array}{c}\text { Aktivitas spesifik } \\
\left(\mathrm{U} \mathrm{mg}^{-1}\right)\end{array}$ & Aktivitas antagonis terhadap G. boninense \\
\hline TB04-05 & 4.00 & 6.3072 & Positif \\
TB04-06 & 3.33 & 5.5151 & Positif \\
TB04-08 & 0.15 & 4.2732 & Positif \\
TB04-13 & 2.85 & 5.6744 & Positif \\
TB04-15 & 1.20 & 5.2599 & Positif \\
TB04-17 & 0.63 & 4.5350 & Positif \\
TB04-18 & 1.13 & 5.4407 & Positif \\
SW02-08 & 0.50. & 6.0385 & Positif \\
SW02-19 & 0.20 & 5.4670 & Positif \\
SW01-11 & 0.67 & 6.1279 & Positif \\
\hline
\end{tabular}


aktivitas spesifik kitinase dari 10 galur kitinolitik berkisar $4.27-6.30 \mathrm{U} \mathrm{mg}^{-1}$ protein (Tabel 2). Aktivitas spesifik kitinase diperoleh dari nisbah antara aktivitas enzim dan kadar protein dari ekstrak kasar. Galur TB04-05, SW01-11, dan SW02-08 memiliki aktivitas enzim spesifik yang tinggi dibandingkan dengan galur lainnya. Uji antagonis galur SW01-11 terhadap $G$. boninense secara in vitro memperlihatkan aktivitas penghambatan dibandingkan dengan kontrol (Gambar 1). Enzim ekstrak kasar dari 3 galur terpilih memiliki persentase penghambatan lebih tinggi terhadap pertumbuhan miselium $G$. boninense dibandingkan dengan uji langsung terhadap galurnya (Gambar 2).

Besarnya persentase penghambatan galur bakteri dan enzim ekstrak kasarnya sejalan dengan besarnya zona hambat antara bakteri dan G. boninense. Zona hambat di sekitar koloni bakteri diduga karena hidrolisis kitin yang dikeluarkan oleh bakteri pada dinding sel G. boninense. Hal ini menyebabkan miselium G. boninense tidak dapat tumbuh mendekati koloni bakteri dan terlihat mengalami kerusakan. Kitinase dan enzim hidrolitik lainnya seperti $\beta$-glukanase merupakan enzim kunci dalam melisiskan dinding sel cendawan yang bekerja secara sinergis (Bormann et al. 1999). Bakteri kitinolitik mempunyai aktivitas antagonisme yang kuat terhadap cendawan patogen dengan mekanisme hiperparasitisme dan antibiotiknya. Beberapa enzim kitinolitiknya toksik pada cendawan patogen penyebab penyakit tanaman budi daya, tetapi tidak pada mikroorganisme lain dalam tanah dan tumbuhan inang (Kloepper 1989). Mekanisme antagonisme pada ketiga

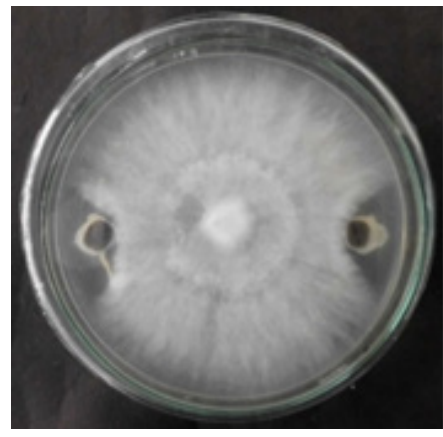

a

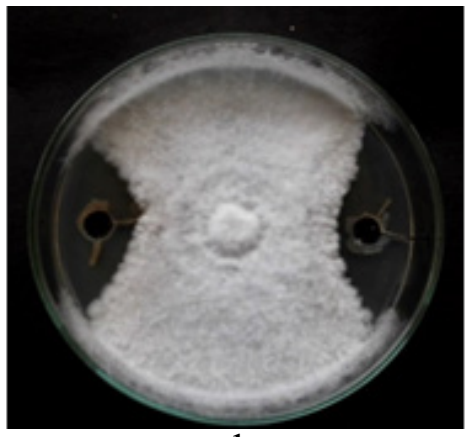

b

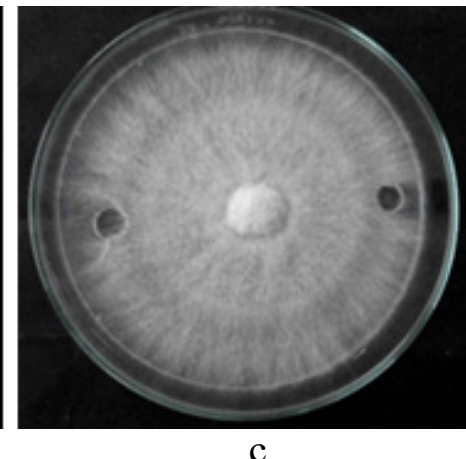

c

Gambar 1 Uji antagonis isolat SW01-11 dan ekstrak kasarnya terhadap Ganoderma boninense setelah inkubasi 5 hari. a, isolat SW01-11; b, Kitinase ekstrak kasar SW01-11; c, Kontrol akuades.

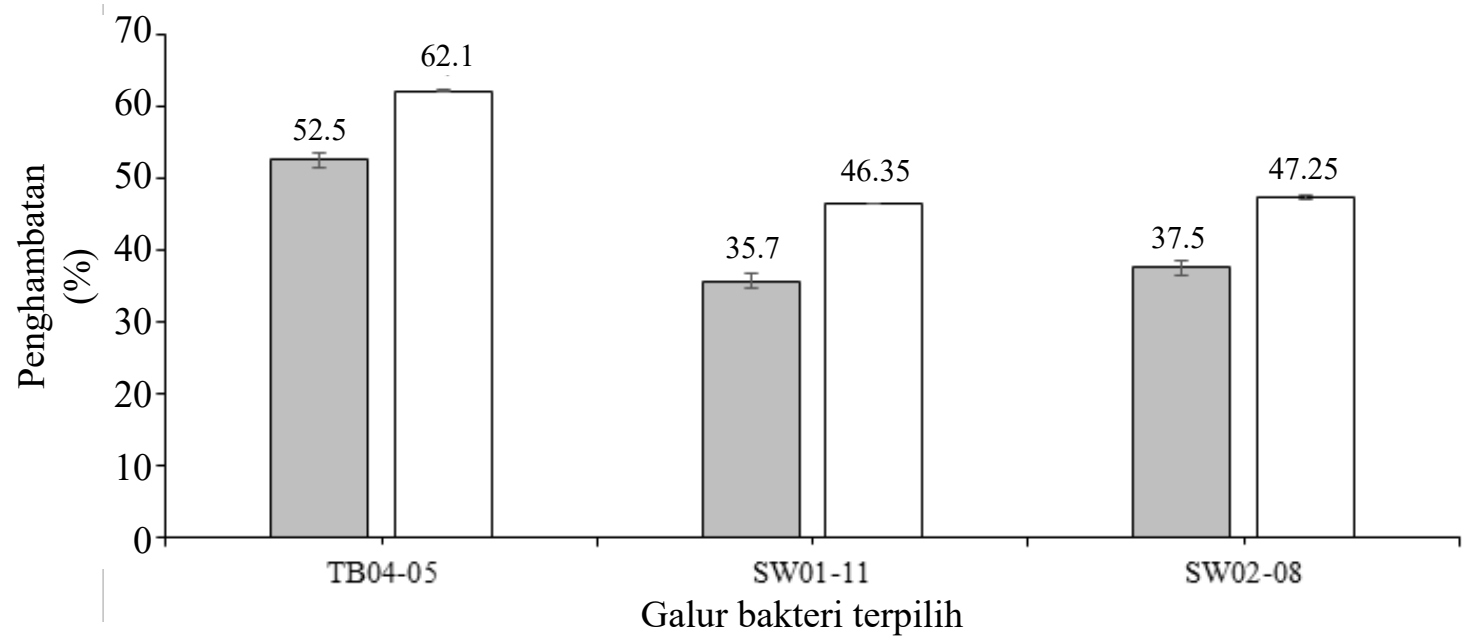

Gambar 2 Penghambatan biakan sel bakteri 24 jam dan ekstrak kasar dari ketiga galur terpilih TB04-05, SW01-11, dan SW02-08 terhadap Ganoderma boninense yang diukur pada hari kelima. $\square$, Kultur sel 24 jam; _, Ekstrak enzim kasar. 
galur uji kemungkinan bertindak sebagai mikoparasit yang sangat aktif. Mikoparasitik terdiri atas empat tahapan, yaitu pertumbuhan kemotropis yang menuju stimulus kimia, pengenalan antara galur bakteri kitinolitik dan patogen tanaman inang yang bersifat spesifik, perlekatan dan pelilitan bakteri pada hifa patogen sasaran, dan proses yang terakhir ialah degradasi dinding sel patogen (Sutanto et al. 2004). Untuk keperluan ini bakteri mengeluarkan enzim kitinase dan glukanase karena komponen utama dinding sel cendawan ialah kitin dan glukan.

Amplifikasi gen 16S rRNA menggunakan primer $63 \mathrm{~F}$ dan $1387 \mathrm{r}$ menghasilkan pita berukuran sekitar $1300 \mathrm{pb}$ (Gambar3). Analisis sikuen gen penyandi $16 \mathrm{~S}$ rRNA dengan data pada GenBank dengan program BLAST-N menunjukkan bahwa galur TB04-05 memiliki kekerabatan dengan Bacillus cereus galur DB33 dengan kemiripan 99\%, Galur SW01-11 memiliki kekerabatan dengan $B$. thuringiensis galur SK783 dengan kemiripan 100\% dan galur SW02-08 memiliki kekerabatan dengan $B$. thuringiensis galur $\mathrm{J} 1$ dengan kemiripan
100\% (Tabel 3). Analisis pohon filogenetika juga menunjukkan bahwa galur SW01-11 dan galur SW02-8 berkerabat dekat dengan $B$. thuringiensis dan galur TB04-05 berkerabat dekat dengan B. cereus (Gambar 4).

Bacillus cereus telah banyak dilaporkan sebagai agens biokontrol pada Alternaria solani dan Corynespora cassiicola, Rhizopus

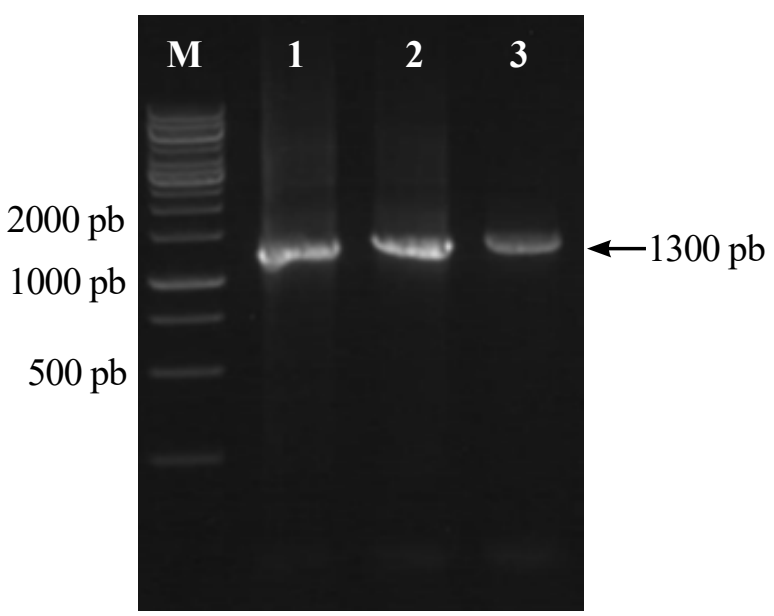

Gambar 3 Amplifikasi DNA galur bakteri terpilih berdasarkan gen 16S RNA pada gel agarosa $1 \%$. M, Penanda DNA $1 \mathrm{~kb} ; 1$, TB04-05; 2, SW01-11; 3, SW02-08.

Tabel 3 Analisis sikuen gen penyandi 16S rRNA 3 galur bakteri terpilih menggunakan program BLAST-N

\begin{tabular}{lccccc}
\hline Galur & No. aksesi & Deskripsi & Quary cover & E-Value & Identitas \\
\hline TB04-05 & KX506717.1 & Bacillus cereus galur_DB33 & $100 \%$ & 0.0 & $99 \%$ \\
SW01-11 & KX595331.1 & Bacillus thuringiensis galur SK783 & $100 \%$ & 0.0 & $100 \%$ \\
SW02-08 & KX935870.1 & Bacillus thuringiensis galur J1 & $100 \%$ & 0.0 & $100 \%$ \\
\hline
\end{tabular}

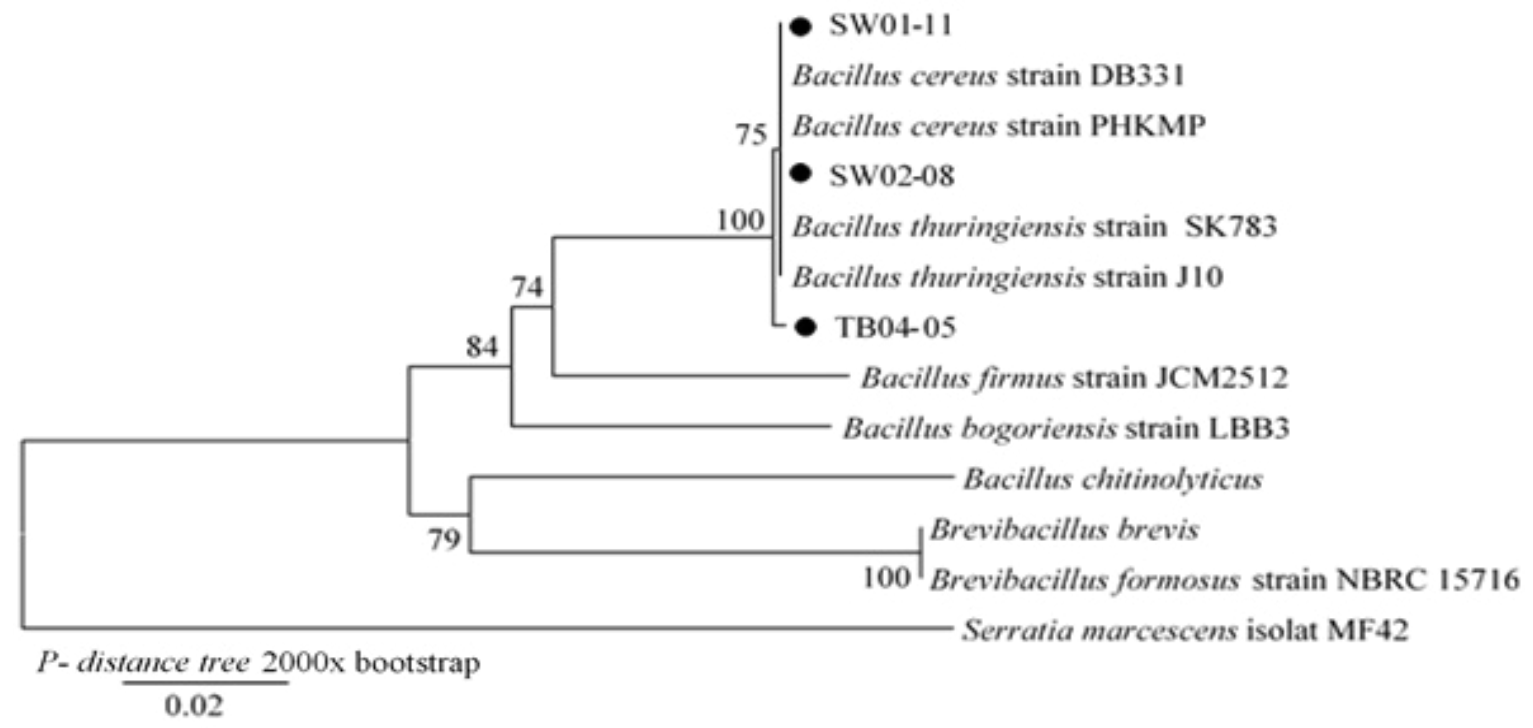

Gambar 4 Pohon filogenetika gen 16S rRNA dari galur TB04-05, SW01-11, dan SW02-08 menggunakan metode Neighbor Joining (NJ) dengan boostrap 2000x. 
stolonifera, Colletotrichum acutatum (Romeiro et al. 2010; Wang et al. 2013; Wang et al. 2014). Bacillus thuringiensis juga dilaporkan sebagai agens biokontrol yang potensial pada Curvularia affinis dan $C$. gloeosporioides (Asril et al. 2014).

Penelitian ini mengklasifikasikan tiga galur memiliki aktivitas spesifik kitinolitik tinggi dan galur yang dapat menghambat pertumbuhan $G$. boninense dan dapat dijadikan sebagai acuan sebagai agens biokontrol. Galur ini dapat diuji secara in planta pada kelapa sawit dan kelak dapat diaplikasikan pada perkebunan kelapa sawit.

\section{UCAPAN TERIMA KASIH}

Terima kasih kepada Dirjen DIKTI melalui Beasiswa Pendidikan Pascasarjana Dalam Negeri (BPPDN) 2013, PhD Grant DIPA Biotrop 2016 nomor: 0044.26/PSRP/SC/SPKPNLT/III/2016 kepada Risky Hadi Wibowo, dan hibah PUPT Dirjen DIKTI Indonesia 2016 nomor: 079/SP2H/LT/DRPM/II/2016 kepada Nisa Rachmania Mubarik.

\section{DAFTAR PUSTAKA}

Asril M, Mubarik NR, Wahyudi AR. 2014. Partial purification of bacterial chitinase as biological control of leaf blight on oil palm. Res J Microbiol. 9(6):265-277. DOI: https://doi.org/10.3923/jm.2014.265.277.

Bivi MR, Farhana MSN, Khairulmazmi A, Idris A, 2010. Control of Ganoderma boninense: a causal agent of basal stem rot disease in oil palm with endophyte bacteria in vitro. Int J Agric Biol. 12:833-839.

Bormann C, Baier D, Ho I, Raps C, Berger J, Jung G, Schwarz H. 1999. Characterization of a novel, antifungal, chitin-binding protein from Streptomyces tendae Tü901 that interferes with growth polarity. J Bacteriol. 181(24):7421-7429.

Cooper RM, Flood J, Rees RW. 2011. Ganoderma boninense in oil palm plantations: current thinking on epidemiology, resistance and pathology. Planter. 87(1024): 515-526.
Duffy BK, Andrew S, DM Weller. 1995. Combination of Trichoderma koningii with fluorescent Pseudomonads for control of take-all on wheat. Phytopathology. 86(2):160-168.

Fokkema NJ. 1973. The role of saprophytic fungi in antagonism against Drechslera sorokiniana (Helminthosporium sativum) on agar plates and on rye leaves with pollen. Phys Plant Pathol. 3(2):195-205. DOI: https://doi.org/10.1016/00484059(73)90082-9.

Haryanto A. 2013. Isolation of chitinolytic bacteria used as biological control of suspected pathogenic fungi on oil palm seedlings [skripsi]. Bogor (ID): Institut Pertanian Bogor.

Kloepper JW, Lifshitz R, Zablotowicz RM. 1989. Free-living bacterial inocula for enhancing crop productivity. Trends Biotechnol. 7:39-43. DOI: https://doi. org/10.1016/0167-7799(89)90057-7.

Lopes MA, Gomes DS, Koblitz MGB, Pirovani CP, Cascardo JCDM, Es-Net AG, Michelia F. 2008. Use of response surface methodology to examine chitinase regulation in the Basidiomycetes Moniliophthora Perniciosa. J Mycol Res. 112(4): 399-406. DOI: https://doi. org/10.1016/j.mycres.2007.10.017.

Marchesi JR, Sato T, Weigtman AJ, Martin TA, Fry JC, Hiom SJ, Wade WG. 1998. Design and evaluation of usefull bacteria spesific PCR primers that amplify genes coding for bacteria 16S rRNA. Appl Environ Microbiol. 64(2):795-799.

Mubarik NR, Mahagiani I, Anindyaputri A, Santoso S, Rusmana I. 2010. Chitinolytic bacteria isolated from chili rhizosphere: chitinase characterization and its application as biocontrol for whitefly. Am J Agric Biol Sci. 5(4):430-435. DOI: https:// doi.org/10.3844/ajabssp.2010.430.435.

Patil RS, Ghormade V, Deshpande MV. 2000. Chitinolytic enzymes: an exploration. Enz Microbiol Technol. 26:473-483. DOI: https://doi.org/10.1016/S01410229(00)00134-4. 
Romeiro RS, Filho RL, Macagnan D, Garcia FAO, Silva HAS. 2010. Evidence that the biocontrol agent Bacillus cereus synthesizes protein that can elicit increased resistance of tomato leaves to Corynespora cassiicola. Tropic Plant Pathol. 35(1):1115. DOI: https://doi.org/10.1590/s198256762010000100002.

Sanjaya I, Yuanita L. 2007. Adsorpsi Pb (II) oleh kitosan hasil isolasi kitin cangkang kepiting bakau (Scylla sp). J Ilmu Dasar. 8(1):30-36.

Suryanto D, Wibowo RH, Siregar EBM, Munir E. 2012. A possibility of chitinolytic bacteria utilization to control basal stem disease caused by Ganoderma boninense in oil palm seedling. Afr J Microbiol. 6(9):2053-2059. DOI: https://doi. org/10.5897/ajmr11.1343.

Sutanto E, Yenny Y, Asmono D, 2004. Hiperparasitisme beberapa agens biokontrol terhadap Ganoderma boninense penyebab penyakit busuk pangkal batang kelapa sawit. J Penel Kelapa Sawit. 10(23):63-68.

Thompson SE, Smith M, Wilkinson MC, Peek K. 2001. Identification and characterization of a chitinase antigen from Pseudomonas aeruginosa strain 385. Appl Environ Microbiol. 67(9):4001-4008. DOI: https://doi.org/10.1128/AEM.67.9.40014008.2001

Wang X, Wang L, Wang J, Jin P, Liu H, et al. 2014. Bacillus cereus AR156induced resistance to Colletotrichum acutatum is associated with priming of defense responses in loquat fruit. PloS ONE 9(11):e112494. DOI: https://doi. org/10.1371/journal.pone.0112494.

Wang XL, Xu F, Wang J, Jin P, Zheng YH. 2013. Bacillus cereus AR156 induces resistance against Rhizopus rot through priming of defense responses inpeach fruit. Food Chem. 136:400-406. DOI: https:// doi.org/10.1016/j.foodchem.2012.09.032. 